\title{
POTENSI PIGMEN ALAMI DARI BAKTERI SIMBION KARANG Mantipora sp SEBAGAI PEWARNA MAKANAN
}

\author{
[Potential of Pigment from Simbion Coral Bacteria Mantipora sp As a Food Color] \\ Dhanang Puspita ${ }^{* *}$, Jacob L.A Uktolseja2) \\ 1) Tekpang FKIK Universitas Kristen Satya Wacana, Salatiga \\ *) Biologi, FB Universitas Kristen Satya Wacana, Salatiga \\ *Email: dhanang.puspita@uksw.edu
}

Diterima 9 September 2019 / Disetujui 06 Juli 2020

\begin{abstract}
Color is very important in the food industry. The need for food coloring requires manufacturers to use synthetic dyes that have the potential to cause poisoning and cancer. One source of natural dyes comes from bacteria that are symbiotic with coral reefs. The purpose of this study is to isolate and characterize the bacterial pigment that has symbiosis with Montipora sp. The research method consisted of bacterial isolation and identification, pigment identification with UV-Vis spectrofotometer $(200-800 \mathrm{~nm})$ and TLC. The results of isilation and identification showed that Rhodococcus sp is dominant bacterial which is produces of carotenoiids for self defense from UV rays. The pigment found in Rhodococcus sp has the potential as a natural pigment for food coloring.
\end{abstract}

Keywords: carotenoids, Montipora, pigment, Rhodococcus sp.

\begin{abstract}
ABSTRAK
Warna sangat penting dalam industri pangan. Kebutuhan pewarna makanan menuntut produsen memakai bahan pewarna sintetik yang berpotensi menyebabkan keracunan dan kanker. Salah satu sumber pewarna alami berasal dari bakteri yang bersimbiosis dengan terumbu karang. Tujuan dari penelitian ini adalah mengisolasi dan mengkarakterisasi pigmen bakteri yang bersimbion Montipora sp. Metode penelitian terdiri dari isolasi dan identifkasi bakteri, identifikasi pigmen dengan spektrofotometer UV-Vis (200 - $800 \mathrm{~nm}$ ) dan KLT. Hasil isolasi dan identifikasi bakteri berjenis Rhodococcus sp dan piigmen yang dihasilkan adalah karotenoid yang digunakan sebagai pertahanan diri dari sinar UV. Pigmen yang terdapat pada Rhodococcus sp berpotensi sebagai pigmen alami untuk pewarna pangan.
\end{abstract}

Kata kunci: karotenoid, Montipora, pigmen, Rhodococcus sp.

\section{PENDAHULUAN}

Warna adalah kesan yang diperoleh mata dari pantulan cahaya-cahaya yang mengenai benda-benda. Benda-benda tersebut memiliki zat warna yang akan menyerap atau memantulkan panjang gelombang tertentu. Warna-warna yang dipantulkan inilah yang akan memberikan kesan sehingga, warna teramatlah penting dalam kehidupan. Dalam industri makanan dan minuman, warna adalah elemen penting dalam sebuah produk. Warna akan memberikan informasi dasar sebuah produk dan menentukan konsumen dalam memilih produk (Winarno, 2004). Begitu pentingnya warna sebagai BTP (Bahan Tambahan Pangan) acapkali tidak mengindahkan keamanan pangan. Pewarna-pewarna sintetis yang tidak layak untuk dikonsumsi dijadikan BTP. Efek samping pewarna sintetis yang tidak langsung terasa menjadikan pemanfaatan pewarna sintetis ini dianggap hal yang lumrah.

Pewarna sintetik memberikan efek samping yang buruk bagi kesehatan. Potensi keracunan hingga ancaman kanker bisa terjadi jika tubuh terus menerus terpapar pewarna ini. Alasan pemanfaatan pewarna sintetik dibanding pewarna alami adalah tingkat kepraktisan, nilai ekonomis, dan kekuatan warna. Pewarna sintentik lebih mudah di peroleh dan murah, mudah pemakaian, dan praktis, serta memiliki warna yang kuat dibanding pewarna alami. Munculnya kesadaran masyarakat akan 
pentingnya kesehatan berkaitan potensi gangguan kesehatan karena pewarna makanan, maka digalakan kembali penggunaan pewarna alami. Pewarna alami merupakan sumber pewarna yang berasal dari tumbuhan, hewan, alga, jamur, dan mikroorganisme. Pewarna alami terbukti lebih aman dibanding dengan pewarna sintetis (Puspita et al., 2018).

Salah satu sumber pewarna alami adalah dari bakteri yang berasal dari terumbu karang. Asosiasi antara bakteri dan karang merupakan faktor penting bagi koloni karang sebagai penyedia nutrient untuk proses konversi cahaya menjadi energi kimia oleh zooxanthellae. Arini (2013) mengatakan bahwa material organik yang ada dalam koloni karang tersedia dalam jumlah yang melimpah sehingga memerlukan dekomposer yaitu bakteri pengurai.

Montipora sp adalah salah satu karang keras bertipe hermatipik yang menghasikan senyawa bioaktif (Speed dan Thamattoor, 2002), yakni menghasilkan warna seperti ungu, merah muda, kuning, dan cokelat. Keberadaan warna pada Mantiopora menjadi indikator keberadaan pigmen. Warna-warna yang ada di Mantiopora adalah senyawa biokatif yang disintesis oleh karang itu sendiri atau simbionnya. Keberadaan bakteri pada karang sangatlah penting karena berperan dalam proses degradasi dan penyedia material organik bagi inangnya. Radjasa et al (2007) menyatakan, simbion karang memiliki kemampuan yangsama dengan inangnya dalam menghasilkan senyawa biokatif dan salah satunya adalah pigmen. Pigmen yang ada di Mantiopora sp diduga terdapat bakteri yang mampu mensintesis warna yang sama dengan inangnya.

Dalam penelitian yang dilakukan oleh Wusqy et al (2014) dikatakan bakteri yang bersimbiosis dengan karang Acropora sp mampu menghasilkan warna yakni pigmen $\beta$ carotene. Warna-warni terumbu karang adalah ekspresi dari pigmen-pigmen yang disintesis. Pigmen-pigmen yang terdapat pada terumbu karang seperti karotenoid akan diekspresikan ke dalam warna merah, merah muda, dan kuning. Tujuan penelitian ini untuk mengisolasi dan mengkarakterisasi pigmen bakteri yang bersimbion Montipora sp.

\section{BAHAN DAN METODE}

Sampel terumbu karang diperoleh dari Pulau Menjangan Kecil-Karimunjawa (koordinat;-5.8833, 110.4000) yang diambil di kedalaman 8 - $23 \mathrm{~m}$ pada 30 Agustus 2015 pukul 08.45. Kemudian sampel karang dihomogenisasai untuk proses pencuplikan bakteri. Bakteri yang sudah dicuplik kemudian diisolasi dan diidentifikasi DNA di PT. Genetika Science Indonesia. Pigmen pada bakteri dianalisis dengan spektrofotometer.

\section{Isolasi Bakteri (Radjasa et al., 2007)}

Terumbu karang diambil dari kedalaman $8-23 m$ dengan penyelaman scuba. Sampel terumbu karang gerus dalam cawan porselin lalu diisolasi dalam medium zobell cair: ekstrak khamir (Oxoid) $(0,5 \%)$, pepton (Oxoid) (0,5\%), glukosa (Merck) (1\%) dan air laut steril $(1.000 \mathrm{ml})$. Selama dalam perjalanan sampel karang dikondisikan dalam suhu dingin $\pm 4 \mathrm{C}^{\circ}$. Isolasi bakteri dilakukan dengan menggunakan medium zobell padat; $5 \mathrm{~g}$ pepton (Oxoid), $1 \mathrm{~g}$ ekstrak khamir (Oxoid), dan $15 \mathrm{~g}$ agar nutrien (Oxoid) dalam 1 liter air laut steril. Pencuplikan dilakukan alam inkass dengan menggunakan jarum ose yang ditempelkan pada sampel lalu digoreskan pada permukaan agar. Inkubasi isolat dilakukan dengan pemaparan dengan cahaya lampu putih dalam suhu ruang $\pm 25^{\circ} \mathrm{C}$ selama $3-7$ hari. Bakteri pembentuk pigmen ditandai dengan koloni yang berwarna. Koloni yang berwarna kemudian dicuplik dan dilakukan penapisan dalam medium isolasi hingga didapatkan koloni tunggal. Isolat murni dipindahkan dalam medium zobell dalam agar miring.

\section{Identifikasi Bakteri (Geneaid, 2017)}

Bakteri simbion didentifikasi dengan cara sebagai berikut: 
1. Ekstraksi DNA mengggunakan Presto ${ }^{\mathrm{TM}}$ Mini gDNA Bacteria Kit (Geneaid);

2. Aplifikasi PCR mengggunakan MyTaq Red Mix (Bioline);

3. Pemurnian sampel PCR menggunakan Zymoclean $^{\text {TM }}$ Gel DNA Recovery Kit (Zymo Research);

4. Sekuensing dengan cara Bi-directional.

\section{Identifikasi Morfologi Bakteri (Fardiaz, 1989)}

$\begin{array}{ccc}\text { Pengamatan morfologi bakteri } & \text { mam. } \\ \text { dilakukan dengan pengecatan gram. }\end{array}$ Pengetan gram dengan menggunakan Gram A (crystal violet), gram B (Methyl Blue), Gram C (alkohol 70\%), dan gram D (Safranin). Setelah dilakukan pengecatan, kemudian diamati dengan menggunakan mikroskop dengan perbesaran $1.600 \times$.

\section{Ekstraksi Pigmen (Amaya, 2005)}

Sebanyak $250 \mathrm{ml}$ sampel bakteri yang ditumbuhkan pada media cair Zobell 2216E disentrifus dengan kecepatan $4000 \mathrm{rpm}$ selama 15 menit pada suhu $4^{\circ} \mathrm{C}$. Pellet yang mengendap dipindahkan ke tabung reaksi, kemudian ditambahkan larutan Acetone (Merck) : Methanol (Merck) dengan perbandingan $7: 3 \mathrm{v} / \mathrm{v}$. Sampel divorteks selama 1 menit. Cairan berwarna diambil kemudian dipindahkan ke tabung reaksi lainnya. Cairan berwarna disaring dengan menggunakan kertas whatman (Sartorius) dengan pori-pori 0,2 $\mu \mathrm{m}$. Hasil saringan dikeringkan dengan menggunakan gas nitrogen. Sampel pigmen karotenoid yang sudah dikeringkan disimpan pada suhu $-20^{\circ} \mathrm{C}$ hingga dilakukan analisis lanjutan.

\section{Analisis Pigmen (Amaya, 2005)}

Sampel pigmen karotenoid dideteksi dengan spektrofotometer UV-Vis Varian Cary pada panjang gelombang 200-800 nm dengan menggunakan pelarut aseton (Merck).

\section{KLT Pigmen (Amaya, 2005)}

Sampel 8B digunakan perbandingan eluen (Metanol (Merck) : Aseton (Merck) : Hexane
(Merck), $1: 1: 1 \mathrm{v} / \mathrm{v} / \mathrm{v})$. Sampel ditotolkan pada plat KLT silika gel 60 ukuran $2 \times 10 \mathrm{~cm}$ yang sudah di plot dengan pensil (dan tangan tidak menyentuh permukaan plat yang mengandung silica gel). Sampel yang sudah ditotolkan dikering anginkan. Lalu, di masukkan ke dalam wadah pengembang (gelas chamber) yang berisi eluen dengan komposisi yang telah ditentukan. Dibiarkan noda mengembang sampai eluen berada pada batas yang sudah di garisi dengan pensil. Kemudian diambil dan dikering anginkan dan di lihat spotnya dibawah sinar UV dan dihitung Rf-nya.

\section{HASIL DAN PEMBAHASAN}

Karang melakukan hubungan simbiotik dengan berbagai bakteri, sehingga permukaan karang dikolonisasi oleh bakteri (DiSalvo, 1971). Dari jenis bakteri itu, ada bakteri yang dapat menghasilkan pigmen karotenoid (Johnson dan Schroeder, 1996). Manfaat pigmen dari bakteri adalah lebih aman digunakan untuk manusia dibandingkan pigmen buatan yang bisa mengandung bahan racun (Nelis dan Leenheer, 1991) Karang Montipora sp. juga bersimbiosis dengan bakteri berkarotenoid.

Berdasarkan hasil ampilfikasi 16S rDNA menunjukan bahwa isolat bakteri $8 \mathrm{~B}$ menghasilkan pita basa 1400 bp sesuai dengan perbandingan menggunakan marker DNA. Hasil visualisasi DNA menggunakan elektroforesis disajikan pada Gambar 1a. Hasil analisis menggunakan BLAST menunjukkan bahwa isolat bakteri $8 \mathrm{~B}$ memiliki kemiripan dengan spesies Rhodococcus sp. dengan homologi sekuen sebesar 99\%. Analisis filogenetik menunjukkan bahwa Rhodococcus sp menggunakan Bi-directional Sequencing disajikan pada Gambar 1b dan hasil analisis menunjukan bahwa isolat $8 \mathrm{~b}$ memiliki hubungan kekerabatan dengan Rhodococcus sp. 


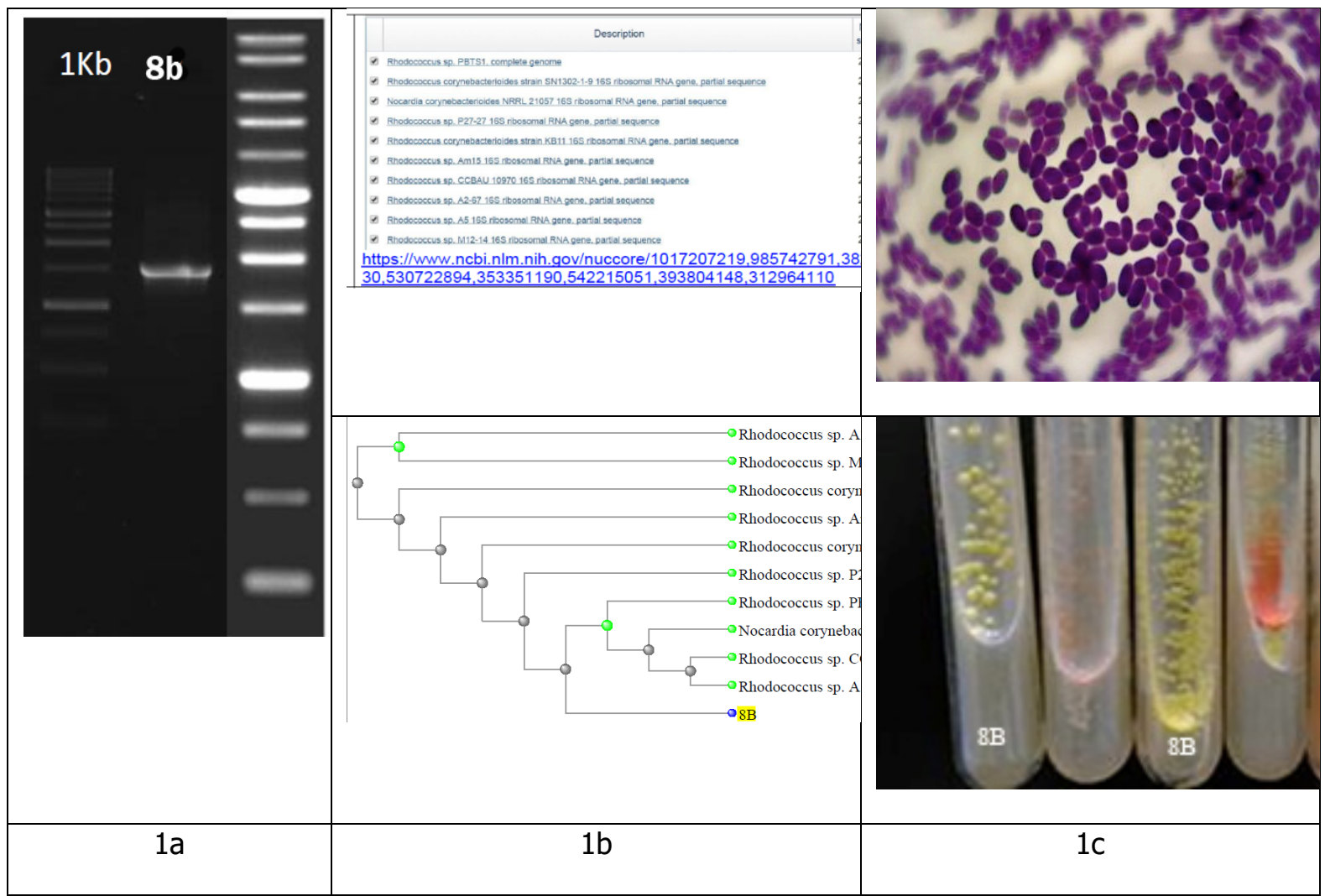

Gambar 1. 1a) Visualisasi DNA menggunakan elektroforesis (kiri); 1b) Filogenetik Rhodococcus sp (sampel 8B) menggunakan Bi-directional Sequencing (kanan) 1c) gambar morfologi dan koloni (8b).

Hasil dari analisis pigmen dengan menggunakan spektrofotometer ditunjukan pada Gambar 2 dengan panjang gelombang dari $200-800 \mathrm{~nm}$, terlihat beberapa puncak gelombang.

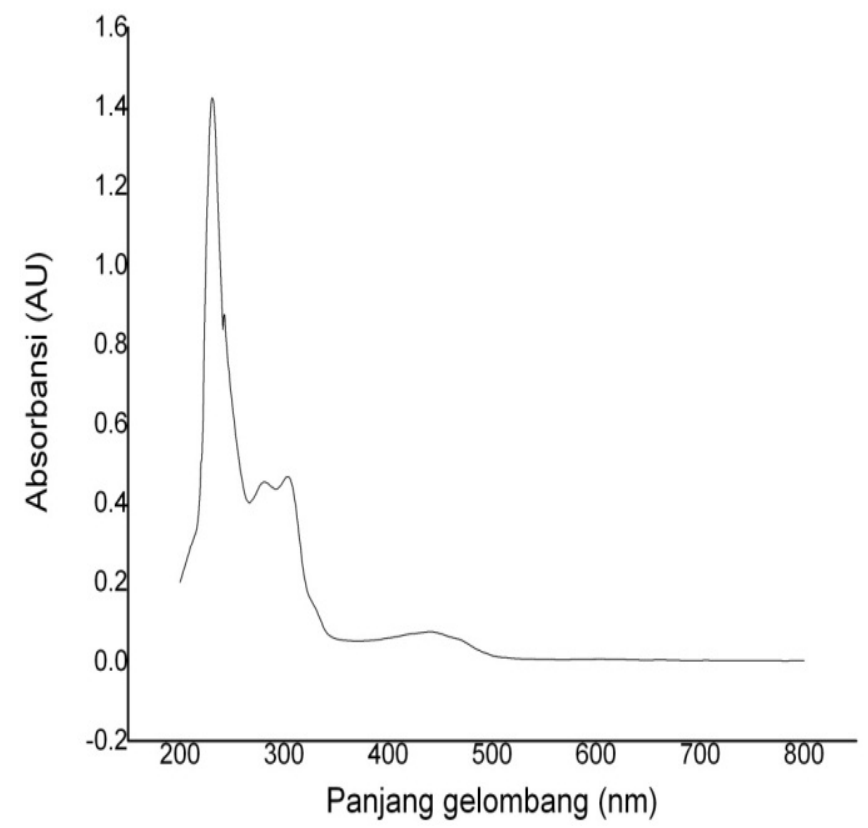

Gambar 2. Pola spektra dari pigmen yang dihasilkan oleh bakteri Rhodococcus sp simbion Motinpora sp. 
Dari hasil KLT Tabel 1, diperoleh 4 fraksi warna dan RF yang berbeda, yakni; kuning tua $(0,41)$, kunimg $(0,54)$, merah muda $(0,56)$, dan merah kecoklatan $(0,60)$.

Tabel 1. Hasil KLT pigmen bakteri

\begin{tabular}{|c|c|c|c|}
\hline Gamb & bar & Warna & RF \\
\hline \multirow{4}{*}{$\frac{1}{m}$} & \multirow{4}{*}{8} & kuning tua & 0,41 \\
\hline & & kuning & 0,54 \\
\hline & & merah muda & 0,56 \\
\hline & & $\begin{array}{l}\text { Merah } \\
\text { kecoklatan }\end{array}$ & 0,60 \\
\hline
\end{tabular}

Mantipora memiliki kandungan senyawa bioaktif diacetylenic. Senyawa diacetylenic terbukti memiliki sitotokisitas terhadap sejumlah sel tumor pada manusia (Speed dan Thamattoor, 2002). Ada kemungkinan, senyawa bioktif tersebut ikut dimiliki oleh salah satu simbionnya yakni Rhodococcus. Genus Rhodococcus terdiri dari actinomycetes gram positif dengan koloni yang berpigmen merah atau merah muda (Hill et al, 1989). Rhodococcus sp yang ditemukan pada habitat laut, mayoritas adalah organisme halofilik, psikrotrofik, dan memiliki warna. Warna yang muncul dari genus Rhodococcus yang diisolasi dari lingkungan laut biasnya merah atau merah muda (Helmke dan Weyland, 1984). Osawa et al (2011) melaporkan, telah mengisolasi carotenoid (OH-chlorobactene glucoside hexadecanoate) dan karotenoid langka $\mathrm{OH}$ chlorobactene glucoside, $\mathrm{OH}$--carotene glucoside dan $\mathrm{OH}$-4-keto-carotene glucoside hexadecanoate dari Rhodococcus sp.

Genus Rhodococcus adalah kelompok bakteri yang sangat beragam dan memiliki kemampuan untuk mereduksi sejumlah senyawa organik, termasuk beberapa senyawa yang paling sulit seperti resalcital. Beberapa strain milik genus Rhodococcus
ISSN: 2443-1095

telah diisolasi dari berbagai lingkungan yang terkontaminasi (Curragh, 1994; Haroune, 2004; Morii, 1998; Prince and Grossman, 2003), yang telah terbukti menjadi kandidat ideal untuk meningkatkan bioremediasi situs yang terkontaminasi dan berbagai biotransformasi, seperti modifikasi steroid, sintesis enantioselektif, dan produksi amida dari nitril (Kim dan Hyun, 2002). Sebagai contoh, Rhodococcus sp strain R04 diisolasi dari tanah yang terkontaminasi minyak di Cina utara mampu melakukan biodegraining polychlorinated biphenyls (PCBs) tidak hanya melalui ring cleavage tetapi juga melalui deklorinasi (Yang, 2007).

Genus Rhodococcus terdiri dari actinomycetes gram positif dengan koloni yang berpigmen merah atau merah muda (Hill et al, 1989). Pada gambar (Gambar 1c), ditunjukan warna koloni berwarna kuning. Warna kuning adalah pigmen yang dibentuk oleh bakteri tersebut dapat diindikasikan sebagai warna astaksantin, kantaksantin, dan Zeasantin (Amaya, 2005). Ketiga pigmen tersebut adalah turunan dari karotenoid.

Dengan ditemukaanya Rhodococcus sp yang mampu memroduksi pigmen warna kuning dapat dijadikan sebagai sumber pigmen yang potensial. Penelitian selanjutnya diharapkan bisa mengetahui secara spesifik jenis pigmen dan besaran produktifitas dalam menghasilkan pigmen. Kedepannya Rhodococcus sp bisa dijadikan sebagai sumber agen hayati yang mampu memroduksi pigmen alami.

\section{Pigmen Rhodococcussp}

Puncak-puncak pola spektra (Gambar 2) pada beberapa panjang gelombang mengindikasikan adanya puncak serapan oleh pigmen-pigmen yang dihasilkan oleh Rhodococcus sp. Terlihat, ada 3 puncak pada panjang gelombang 200-300 nm yang merupakan rentangan cahaya UV-B.

Cahaya UV-B dapat merusak DNA dan protein jika terpapar terus-menerus. Beberapa mikroba seperti bakteri dan ragi memiliki karotenoid yang mampu menyerap UV-B (Hirabayashi et al., 2004; Kilian et al. , 2007; Moline et al., 2009; Libkind et al, 
2009) sebagai mekanisme perlindungan terhadap fotooksidasi dan stabilisasi membran sel pada suhu tinggi (Yamano et al., 2002; Lutnaes et al., 2004).

Chen et al. (2017) menemukan sekitar 14 senyawa karotenoid dan isoprenoid kuinon (isoprenoid quinones) yang diisolasi dari pigmen Rhodococcus sp. B7740, dengan puncak serapan antara $200-300 \mathrm{~nm}$. (Ichiyama et al., 1989) menemukan warna kuning oranye, merah muda salmon, dan merah tua dengan puncak serapan antara $400-500 \mathrm{~nm}$.

Karotenoid yang diisolasi pada bakteri simbion karang pada penelitian ini, didominansi oleh pigmen warna kuning dengan serapan maksimum lebih rendah dari kebanyakan pigmen warna kuning cahaya tampak. Pigmen kuning cahaya tampak dengan panjang gelombang sekitar 400 $500 \mathrm{~nm}$ tidak banyak terisolasi untuk dapat dideteksi oleh spektrofotometer. Amaya (2001) mengatakan, serapan maksimal pada panjang gelombang $400-500 \mathrm{~nm}$ dengan pelarut aseton akan menyerap beberapa spektrum warna/pigmen. Pada panjang gelombang $448 \mathrm{~nm}$ (a-carotenoid, panjang gelombang 480 (astaxanthin), dan panjang gelombang $452 \mathrm{~nm}$ ( $\beta$-carotenoid dan zeaxanthin).

Dari hasil analisis menggunakan KLT seperti ditunjukan pada Tabel 1, menunjukan ada empat fraksi warna yang terpisah. Empat fraksi warna tersebut terpisah berdasarkan berat molekulnya masing-masing dan sifat kelarutannya. Warna kuning tua, kuning muda, merah mudah, dan merah kecoklatan adalah indikasi warna dari karotenoid.

\section{Pemanfaatan Pigmen Alami}

Karotenoid tidak semata-mata bertanggung jawab atas pembentukan warna merah, merah muda, dan kuning tetapi ada manfaat lain. Di dalam dunia medis dan industri farmasi, dan industri pangan, karotenoid berfungsi sebagai; sumber vitamin A, anti kanker, sumber antioksidan, dan pewarna alami untuk makanan dan minuman.
Di dalam industri makanan dan minuman pemanfaatan pewarna sebagai BTP (bahan tambahan pangan) dapat digunakan untuk memberi nilai tambah pada produk. Penambahan BTP yang tidak baik dan benar akan memberikan potensi gangguan kesehatan. Dari permasalahan inilah yang memunculkan gagasan pemanfaatan pewarna alami sebagai BTP yang jauh lebih aman. Karotenoid dari bakteri (biopigmen) yang bersimbiosis dengan terumbu karang bisa menjadi alternatif sebagai BTP yang aman.

Kelebihan pemanfaatan pigmen alami dari bakteri adalah tidak diperlukannya lahan yang luas dan waktu yang lama saat memanen pigmen, jika dibandingan dengan pigmen dari hewan atau tumbuhan. Dalam waktu singkat dapat dihasilkan pigmen dari bakteri yang ditumbuh kembangkan dalam bioreaktor. Untuk kedepannya, pigmen dari bakteri bisa menjadi penyuplai pigmen alami untuk pemenuhan kebutuhan pigmen dalam berbagai bidang industri. Dengan terpenuhinya kebutuhan pigmen alami maka akan menekan penggunaan pigmen sintetik, sehingga permasalahan berkaitan dengan efek samping pigmen sintetik bisa ditekan.

\section{KESIMPULAN}

Bakteri simbion yang diisolasi dari Motipora sp adalah Rhodococcus yang menghasilkan pigmen warna kuning (karotenoid) Tiga puncak pd pnjng gel 200$300 \mathrm{~nm}$ adalah rentangan cahaya uv-B dan dengan KLT terdpt 4 fraksi warna yakni; kuning tua, kuning muda, merah mudah, dan merah kecoklatan. Pigmen tersebut dapat berpotensi digunakan sbg pewarna alami pangan.

\section{UCAPAN TERIMA KASIH}

Kami mengucapkan terimakasih pada lab CARC (Carotenoid and Antioxidant Research Center) UKSW yang telah menyediakan peralatan dan bahan-bahan kimia untuk penelitian dan analisis. 


\section{DAFTAR PUSTAKA}

Amaya, D.B.R. 2005. A Guide To Carotenoid Analysis in Food. ILSI Press. Washington.

Arini, D.I.D. 2013. Potensi Terumbu Karang Indonesia"Tantangan dan Upaya Konservasinya" The Challengeand Conservation Efforts of Indonesian Coral Reefs. INFO BPK Manado Vol.3 No.2.

Chen, Y., Xie, B., Yang, J., Chen, J., Sun, Z.. 2017. Identification of microbial carotenoids and isoprenoid quinones from Rhodococcus sp. B7740 and its stability in the presence of iron in model gastric conditions. Food Chemistry doi: http://dx.doi.org/10.1016/j.foodchem. 2017.06.067

Curragh, H. 1994. Haloalkane degradation and assimilation by Rhodococcus rhodochrous NCIMB 13064. Microbiology 140:1433-1442

DiSalvo, L,H. 1971. Regenerative function and microbial ecology of coral reefs: labeled bacteria in a coral reef microcosm. J Exp Mar Biol Ecol $7: 123-136$

Fardiaz, S. 1989. Penuntun Praktikum Mikrobiologi Pangan. IPB. Bogor.

Geneaid. 2017. Instruction Manual Presto ${ }^{\mathrm{TM}}$ Mini RNA Bacteria Kit.Geneaid Biotech Ltd.

https://www.geneaid.com/sites/default /files/RBB21.pdf

Haroune, N. 2004. Metabolism of 2mercaptobenzothiazole by Rhodococcus rhodochrous. Appl. Environ. Microbiol. 70:6315-6319

Helmke, R., Weyland, H. 1984. Rhodococcus marinonascecs sp. Nob., an Actinomycete frem the Sea. International Journal of Systematic Bacteriology. 34)2):127-128.

Hill, R., Hart S., Illing, N., Kirby, R., Wood, D.R. 1989. Cloning and Expression of Rhodococcus Genes Encoding Pigment Production in Escherichia coli. Journal of General Microbiology 13: 15071513.
ISSN: 2443-1095

Hirabayashi, H., Ishii, T., Takaichi, S., Inoue, K., Uehara, K. 2004. The role of carotenoids in the photoadaptation of the brown-colored sulfur bacterium Chlorobium phaeobacteroides. Photochem Photobiol 79:280-285.

http://www.mdpi.com/20726643/6/2/546/ht m (diakses 30 September 2019)

Ichiyama, S., Shimakata, K., S., Tsukamura, M., 1989. Carotenoid pigments of genus Rhodococcus. Micobial Immunol 33:503-508.

Johnson, E.A. and Schroeder,W.A. 1996. Microbial carotenoids. Advances in biochemical engineering/biotechnology 53:119-178.

Kilian O., Steunou A.S., Fazeli F., Bailey S., Bhaya D., Grossman, A.R. 2007. Responses of a thermophilic Synechococcus isolate from the microbial mat of Octopus Spring to light. Appl Environ Microbiol 73:42684278

Kim, B. Y., and H. H. Hyun. 2002. Production of acrylamide using immobi- lized cells of Rhodococcus rhodochrous M33. Biotechnol. Bioproc. Eng. 7:194-200

Libkind, D., Moline, M., Sampaio, J.P., van Broock, M. 2009. Yeasts from highaltitude lakes: influence of UV radiation. FEMS Microbiol Ecol 69:353362.

Lutnaes, B.F., Strand, A., Petursdottir, S.K., Liaaen-Jensen, S. 2004. Carotenoids of thermophilic bacteria - Rhodothermus marinus from submarine Icelandic hot springs. Biochem Syst Ecol 32:455-468

Moline, M., Libkind, D., Dieguez Mdel C., van Broock, M. 2009. Photoprotective role of carotenoids in yeasts: Response to UV-B of pigmented and naturallyoccurring albino strains. J Photochem Photobiol B 95:156-161.

Morii, S. 1998. 3-Ketosteroid-delta1dehydrogenase of Rhodococcus rhodochrous: sequencing of the genomic DNA and hyperexpression, purifi- cation, and characterization of the recombinant enzyme. J. Biochem. 124: 1026-1032.

Nelis, H.J., de Leenheer, A.P. 1991. Microbial sources of carotenoid pigments used in 
foods and feeds. Journal of Applied Bacteriology 70:181-191.

Osawa, A., Kasahara, S., Mastuoka, S., Gassel, S., Sandmann, G., Shindo, K. 2011. Isolation of a Novel Carotenoid, OH-chlorobactene Glucoside Hexadecanoate, and Related Rare Carotenoids from Rhodococcus sp. CIP and Their Antioxidative Activities. Biosci. Biotechnol. Biochem., 75 (11), 2142-2147.

Prince, R. C., and M. J. Grossman. 2003. Substrate preferences

in biodesulfurization of diesel range fuels by Rhodococcus sp. strain ECRD-1. Appl. Environ. Microbiol. 69:58335838.

Puspita, D., Tjahyono, Y.D., Samalukang, Y., Toy, B.A.I., Totoda, N.W. 2018. PRODUKSI ANTOSIANIN DARI DAUN MIANA (Plectranthus scutellarioides) SEBAGAI PEWARNA ALAMI. Pro Food (Jurnal Ilmu dan Teknologi Pangan). 4(1):298-303.

Radjasa, O.K., S.I.O. Salasia, A. Sabdono, J. Weise, J.F. Imhoff, C. Lammler, and M.J. Risk. 2007. Antibacterial activity of marine bacterium Pseudomonas sp associated with soft coral Sinularia polydactyla and against Streptococcus equi Subsp. zooepidemicus. Int. J. of pharmacology, 3(2):170-174

Speed T.J, Thamattoor D.M. 2002. Synthesis of montiporynes $A$ and $B$. Tetrahedron Letters 43. 367-369.2002

Winarno F.G. 2004. Kimia Pangan dan Gizi. Gramedia Pustaka Utama. Jakarta.

Wusqy, N.K. Limantara L, Karwur F.K. 2014. Exploration, Isolation and Quantification of $\beta$-carotene from Bacterial Symbion of Acropora sp. Micriobiology Indonesia. Vol.8, No.2, June 2014 (58-64)

Yang, X. Q., . 2007. Characterization and functional analysis of a new gene cluster involved in biphenyl/PCB degradation in Rhodococcus sp. strain R04. J. Appl. Microbiol. 103:22142224.

Yamano, Y., Sakai, Y., Hara, M., Ito, M. 2002. Carotenoids and related polyenes. Part 9. Total synthesis of thermozeaxanthin and
ISSN: 2443-1095

thermocryptoxanthin and the stabilizing effect of thermozeaxanthin on liposomes. J Chem Soc Perk T 1:2006-2013. 